\title{
Effect of Stocking Density on Growth and Survival of Fenneropenaeus merguiensis (de Man, 1888) Post Larvae
}

\author{
Vivek Shrivastava ${ }^{1}$, N.K. Chadha ${ }^{1}$, Md. Koya ${ }^{2}$, W.S. Lakra ${ }^{1}$, \\ Paramita Banerjee Sawant ${ }^{1}$ and S. Remya ${ }^{3}$
}

\author{
${ }^{1}$ ICAR - Central Institute of Fisheries Education, Andheri (W), Mumabi-400061, India \\ ${ }^{2}$ ICAR - Central Marine Fisheries Research Institute, ${ }^{3}$ ICAR - Central Institute of Fisheries \\ Technology, Veraval-3622 269, Gujarat, India \\ *Corresponding author
}

\begin{tabular}{|c|c|}
\hline & A B S T R A C T \\
\hline Keywords & \multirow{4}{*}{$\begin{array}{l}\text { The present study evaluated the effect of stocking density on growth and survival of post } \\
\text { larvae (PL) of Fenneropenaeus merguiensis (de Man, 1888), commonly known as banana } \\
\text { shrimp. PL was stocked at four different densities i.e., 10, 20, 30 and } 40 / \mathrm{m}^{2}(\mathrm{~T} 10, \mathrm{~T} 20 \text {, } \\
\text { T30 and T40, respectively) and reared for a period of } 60 \text { days. Water quality and growth } \\
\text { performance parameters of different treatments were compared during the experiment. A } \\
\text { significant ( }<0.05 \text { ) decrease in dissolved oxygen (DO) concentration relative with the } \\
\text { higher stocking density was observed. Though some of the parameters showed significant } \\
\text { (p<0.05) difference among the treatments, the water quality remained within safe level, } \\
\text { throughout the experiment. Increase in stocking density led to significant reduction } \\
\text { (p<0.05) in BWG and SGR of PL. The highest value of FCR was in T40 and lowest in } \\
\text { T10. Stocking density also showed an inverse relationship with survival percentage of } \\
\text { shrimp. Results of the present study revealed that high stocking density }\left(\geq 30 / \mathrm{m}^{2}\right) \text { can } \\
\text { seriously impair the growth of F. merguiensis PL. }\end{array}$} \\
\hline $\begin{array}{l}\text { Banana shrimp, } \\
\text { FCR, Growth } \\
\text { parameters, } \\
\text { Shrimp culture, } \\
\text { Water quality. }\end{array}$ & \\
\hline Article Info & \\
\hline $\begin{array}{l}\text { Accepted: } \\
\text { 21 July } 2017 \\
\text { Available Online: } \\
\text { 10 September } 2017\end{array}$ & \\
\hline
\end{tabular}

\section{Introduction}

Shrimp, which earns huge revenue through export, is an important aquaculture commodity in India. Several studies revealed that Fenneropenaeus merguiensis, popularly known as banana shrimp, which are found throughout the Asian and Australian tropical and subtropical waters, is a promising candidate species for aquaculture (Zacharia and Kakati, 2002). F. merguiensis has attracted researchers and farmers because of certain advantages like captive breeding in pond, tolerance to low water quality, euryhaline and eurythermal nature, it's readily availability in the wild, good performance during high stocking densities, low protein requirement, minimal size variation during grow out phase, and cheap availability of wild brooders. Above that, rearing of larvae and post larvae of $F$. merguiensis is comparatively easy (Hoang, 2002).

According to FAO (2010), F. merguiensis is a high value commodity for shrimp culture with the ability to attain fast growth rate and forms $5.5 \%$ of the total shrimp (Truong et al., 1995) globally. 
Growth and survival of aquatic organisms, which together determine the ultimate yield, are influenced by a number of ecological parameters and managerial practices. At present, a transitional nursery phase between the hatchery and grow-out ponds is a common practice in shrimp farming industry in many countries (Correia et al., 2014). This three phasing farming system has lots of benefits. Nevertheless, high stocking density in the nursery phase may affect the growth and survival of shrimp due to an increase in cannibalism and degradation of water quality (Wasielesky et al., 2013). Determining the optimum stocking density of the animals being reared is thus very important for the farmers, to maximize production and profitability. However, so far, no studies have been undertaken to investigate the influence of stocking density on the growth and survival of $F$. merguiensis PL under captive condition. Hence, the present work was aimed at studying the performance of $F$. merguiensis post larvae reared in nursery tanks at four different stocking densities.

\section{Materials and Methods}

\section{Experimental animal}

Post Larvae (PL15-20) of banana shrimp, Fenneropenaeus merguiensis (de Man, 1888), (30 days old), proured from ICAR-CIBA, Chennai, were procured from "Soil and Water Management Research Unit", Navsari Agriculture University (NAV), Gujarat. The average length and weight of PL were 1.02 $\mathrm{cm}$ and $0.01 \mathrm{~g}$, respectively.

\section{Site of the experiments}

The experiments were conducted in the wet lab of Veraval Regional Centre of ICARCentral Marine Fisheries Research institute (CMFRI) at Veraval, Gujarat. Subsequently, analysis work was carried out in the water and soil chemistry laboratory of the same institute. Feed formulation and related analysis were undertaken in the feed mill and biochemistry laboratory in the fish processing section of Veraval Research Centre of ICAR-Central Institute of Fisheries Technology (CIFT) at Veraval, Gujarat.

\section{Acclimatization of $F$. merguiensis post larvae}

Post larvae of $F$. merguiensis were acclimatized in the rectangular tanks $(100 \times 50 \times 50 \mathrm{~cm})$ for 15 days. During this period, optimum water quality parameters (Dissolved oxygen, $\mathrm{pH}$, temperature, salinity, TAN) were maintained. Feeding, siphoning, aeration and water exchange were done meticulously. Feeding frequency was maintained at four times $(06.00 \mathrm{hrs}, 12.00 \mathrm{hrs}$, $18.00 \mathrm{hrs}$ and $24.00 \mathrm{hrs}$.) with $100 \%$ body weight.

\section{Experiment}

An experimental trial of 60 days was conducted to understand the effect of stocking density on the growth and survival of hatchery raised post larvae of $F$. merguiensis, in laboratory conditions. After acclimatization for a period of fifteen days, $F$. merguiensis $\mathrm{PL}$ were stocked in a FRP tank of 70 L capacity in the wet laboratory. Healthy PL were segregated and stocked in pre-cleaned tanks at different stocking densities i.e., 10 (T10), 20 (T20), 30 (T30) and 40 (T40) numbers $/ \mathrm{m}^{2}$. Aggregate initial weight of PL was taken using an electronic balance. The average weight of PL was found in the range of $0.35 \pm 0.05 \mathrm{~g}$. All the experimental units received $10 \%$ water exchange daily and 100 $\%$ exchange of water on weekends. The commercial feed "Godrej Agrovet" was used to feed the shrimp PL. Aeration was paused at the time of feeding and siphoning of the tank while continuous aeration was maintained for 
rest of the time. Siphoning was done eight times per day, after an hour of feeding for collecting the left over feed and before the next feeding schedule for collecting the excreta. Physico-chemical quality parameters of water in the experimental tanks and growth performance parameters of PL of $F$. merguiensis were analyzed at regular intervals throughout the experiment.

\section{Analysis of physico-chemical quality parameters of water}

Temperature of water in the experimental tanks was measured in the morning and evening using mercury thermometer and expressed as ${ }^{\circ} \mathrm{C}$. $\mathrm{pH}$ (hydrogen ion concentration) of the water in all the experimental tanks was tested using a digital $\mathrm{pH}$ meter and salinity of the water was measured by salinity refractometer. The DO level in water was estimated according to Winkler's method (APHA, 1995). The level of total ammonia (NH3)-N (TAN) was estimated using spectrophotometer at a wavelength of $640 \mathrm{~nm}$ by phenate method (APHA, 1998) and nitrite-N $\left(\mathrm{No}_{2}-\mathrm{N}\right)$ and nitrate-N $\left(\mathrm{No}_{3}-\mathrm{N}\right)$ concentration was measured (APHA, 1998) at $543 \mathrm{~nm}$ using UV-VIS spectrophotometer and compared with standard graph. Phosphate (PO4-P) concentration was measured (APHA, 1998) at $693 \mathrm{~nm}$ using UV-VIS spectrophotometer and concentration was expressed as $\mathrm{mgL}^{-1}$.

\section{Evaluation of growth performance parameters}

Growth performance parameters of PL of $F$. merguiensis like \% body weight gain (BWG), specific growth rate (SGR), feed conversion ratio (FCR), feed conversion efficiency (FCE), protein efficiency ratio (PER) and survival percentage were analyzed. The percentage BWG and SGR of $F$. merguiensis were evaluated by taking its body weight at
15 days interval. Digital weighing balance was used to measure the weight of the shrimps. The following formulas were used to evaluate the growth of $F$. merguiensis.

BWG $(\%)=($ Final weight - Initial weight $) \times$ 100/ Initial weight

SGR $(\%)=[(\mathrm{Ln}$ final weight - initial weight)/number of days] $\times 100$

$$
\begin{gathered}
\text { PER }=\frac{\text { Wet weight gain }(\mathrm{g})}{\text { Dry protein intake }(\mathrm{g})} \\
\mathrm{FCR}=\frac{\text { Dry feed intake }(\mathrm{g})}{\text { Wet weight gain }(\mathrm{g})}
\end{gathered}
$$

FCE $(\%)=$ Wet weight gain $(\mathrm{g}) /$ Feed consumed $(\mathrm{g})$ x 100

Total number of shrimps harvested

Survival $(\%)=$ $\times 100$

Total number of shrimps stocked

\section{Statistical analysis}

The data were analyzed by statistical package for social science (SPSS) software version 16.0. Significance difference between means was determined using Duncan's multiplerange test (DMRT). The level of significance was set up at $p \leq 0.05$.

\section{Results and Discussion}

Stocking density plays an important role in growth and survival of any cultured organism. Globally, super-intensive production of shrimp is gaining popularity as a possible way to improve aquaculture production (Liu et al., 2017). However, there are few studies on growth performance of $F$. merguiensis $\mathrm{PL}$ stocked at different densities. In the present study, different stocking densities (10 (T10), 
20 (T20), 30 (T30) and 40 (T40) numbers $/ \mathrm{m}^{2}$ ) were used for optimization and to analyze its effect on growth and survival of $F$. merguiensis.

\section{Physico-chemical quality parameters of water}

Stocking density can affect the shrimp, if water quality declines with increasing density. The deteriorated water quality can cause stress in shrimp leading to reduction in growth (Liu et al., 2017, Aguilar et al., 2012). Hence, the quality parameters of water need to be checked regularly during shrimp rearing. The physico-chemical quality parameters of the water in the present experimental tanks are shown in table 1 . Temperature is a very important environmental factor, which strongly influences the growth of shrimps (Bray and Lawrence, 1992). Temperature ranging from 24 to $32^{\circ} \mathrm{C}$ is optimum for penaeid larval culture. Throughout the experimental period, the water temperature of the experimental tanks was found between $27.32{ }^{\circ} \mathrm{C}$ to $27.69^{\circ} \mathrm{C}$. There was no significant difference $(p>0.05)$ in the temperature of the tanks with increase in stocking density. Water used for experiment was pre-collected from sea shore and after filtering, stored for further use. Evaporation loss is maintained by adding fresh water, to keep the salinity constant. Although salinity of water in the tanks decreased, when stocking density increased, the decrease was not significant $(p>0.05)$. Salinity of water in the tanks during experimental period ranged from $31.73 \pm 0.29$ to $32.01 \pm 0.23 \mathrm{ppt}$ as given in table 1 . Hudinaga (1942) and Cook and Murphy (1969) reported that salinity from 27 to $34 \mathrm{ppt}$ was suitable for development of penaeid larvae. Saldanha and Achuthankutty (2000) suggested that the optimum $\mathrm{pH}$ for the growth of $F$. merguiensis is 7.8 to 8.7. The values of $\mathrm{pH}$ in the present experiment, match with the findings of Wang (2004) in L. vannamie culture. The $\mathrm{pH}$ values of water ranged from $7.9 \pm 0.05$ to $8.1 \pm 0.20$, for experimental tanks with different stocking densities. There was no significant $(\mathrm{p}<0.05)$ difference observed in $\mathrm{pH}$ values with the higher stocking density. Several previous researchers have suggested that optimum dissolved oxygen level for penaeid culture is 5.23 to $7.10 \mathrm{mg} / \mathrm{L}$. During the experimental period, DO of the water in the tanks was found in the range of $5.18 \pm$ 0.04 to $6.16 \pm 0.90 \mathrm{mg} / \mathrm{L}$, which was well within the acceptable range. In general, dissolved oxygen level varies with water temperature, metabolic rate, biomass density etc. In the current study, highest DO level was recorded in T10 and lowest in T40 corresponding to lowest and highest stocking density. Similar observation was done by Rahman and Rahman (2003). The DO level of water in various tanks showed significant difference $(\mathrm{p}<0.05)$ with increase in the stocking density as observed by Balakrishnan et al., (2011) in pond condition for $L$. Vannamei and Shyne Anand et al., (2014) for F. merguiensis.

Total ammonia (NH3)-N (TAN), Nitrite $\left(\mathrm{NO}_{2}-\mathrm{N}\right)$ and Nitrate $\left(\mathrm{NO}_{3}-\mathrm{N}\right)$ are important water quality parameters, which indirectly hamper the growth and survival of shrimp. TAN is very crucial for culture of aquatic organisms. In the present study, though there was a significant increase $(p<0.05)$ in the level of TAN, mean values of TAN in all the treatments remained below toxic levels throughout the experimental period. The observed values of TAN were from $0.20 \pm$ 0.03 to $0.34 \pm 0.01 \mathrm{mg} / \mathrm{L}$ and the values for $\mathrm{NO}_{2}-\mathrm{N}$, during the experiment, ranged from $0.12 \pm 0.02$ to $0.17 \pm 0.03 \mathrm{mg} / \mathrm{L}$ as shown in table 2. The level of $\mathrm{NO}_{2}-\mathrm{N}$ increased from T10 to T40 and did not differ significantly. Mean values of $\mathrm{NO}_{3}-\mathrm{N}$ fell in the range from $0.22 \pm 0.02$ to $0.41 \pm 0.04 \mathrm{mg} / \mathrm{L}$. There was significant $(\mathrm{p}<0.05)$ increase in the $\mathrm{NO}_{3}-\mathrm{N}$ level with increase in stocking density. 
Fig.1 BWG (\%) of PL of $F$. merguiensis during rearing of 60 days in FRP tanks at different stocking density

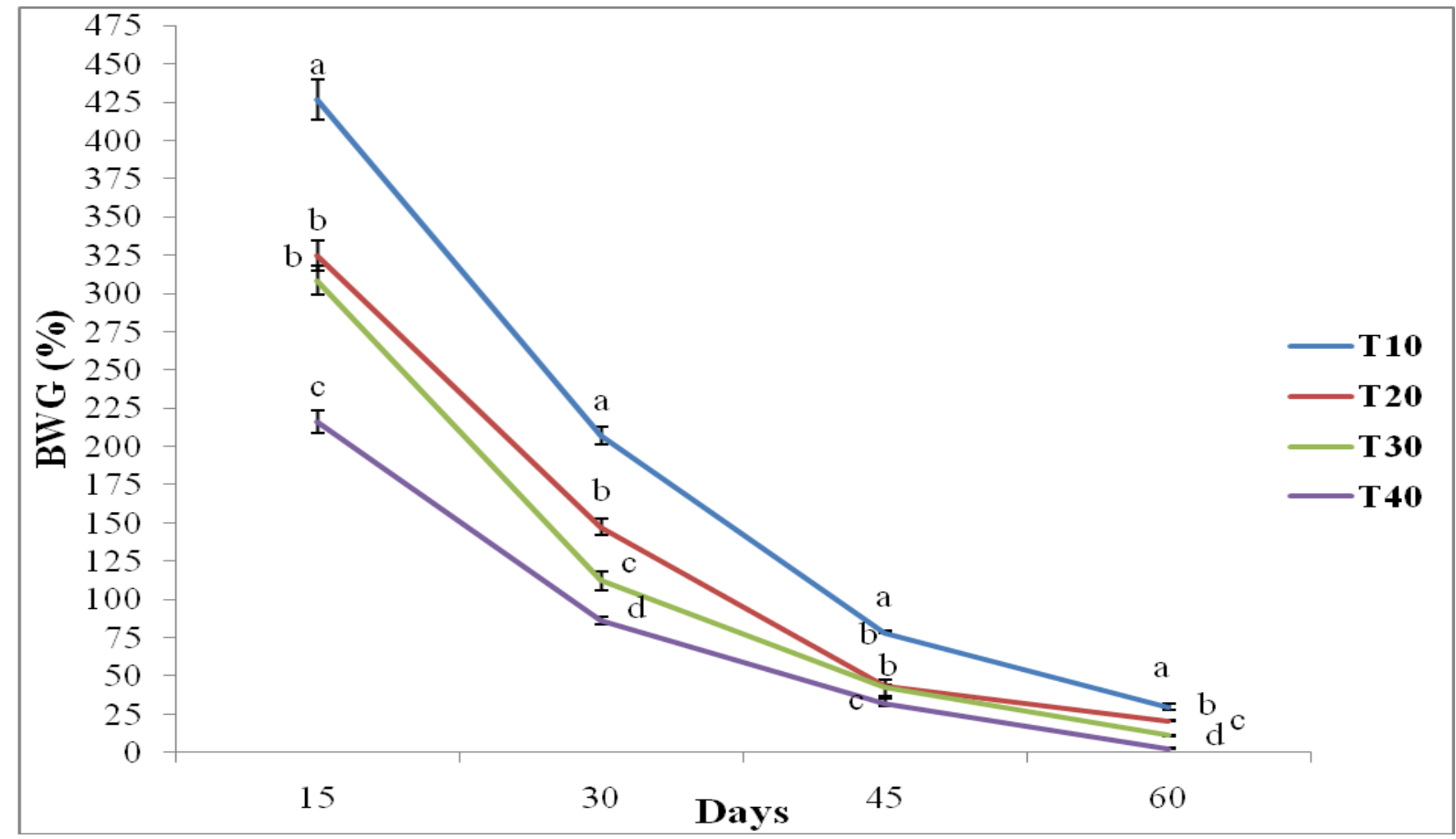

*Means \pm SD in the same column with different superscripts are significantly different $(\mathrm{p}<0.05)$

Fig.2 SGR of PL of $F$. merguiensis during 60 days rearing in FRP tanks at different stocking density

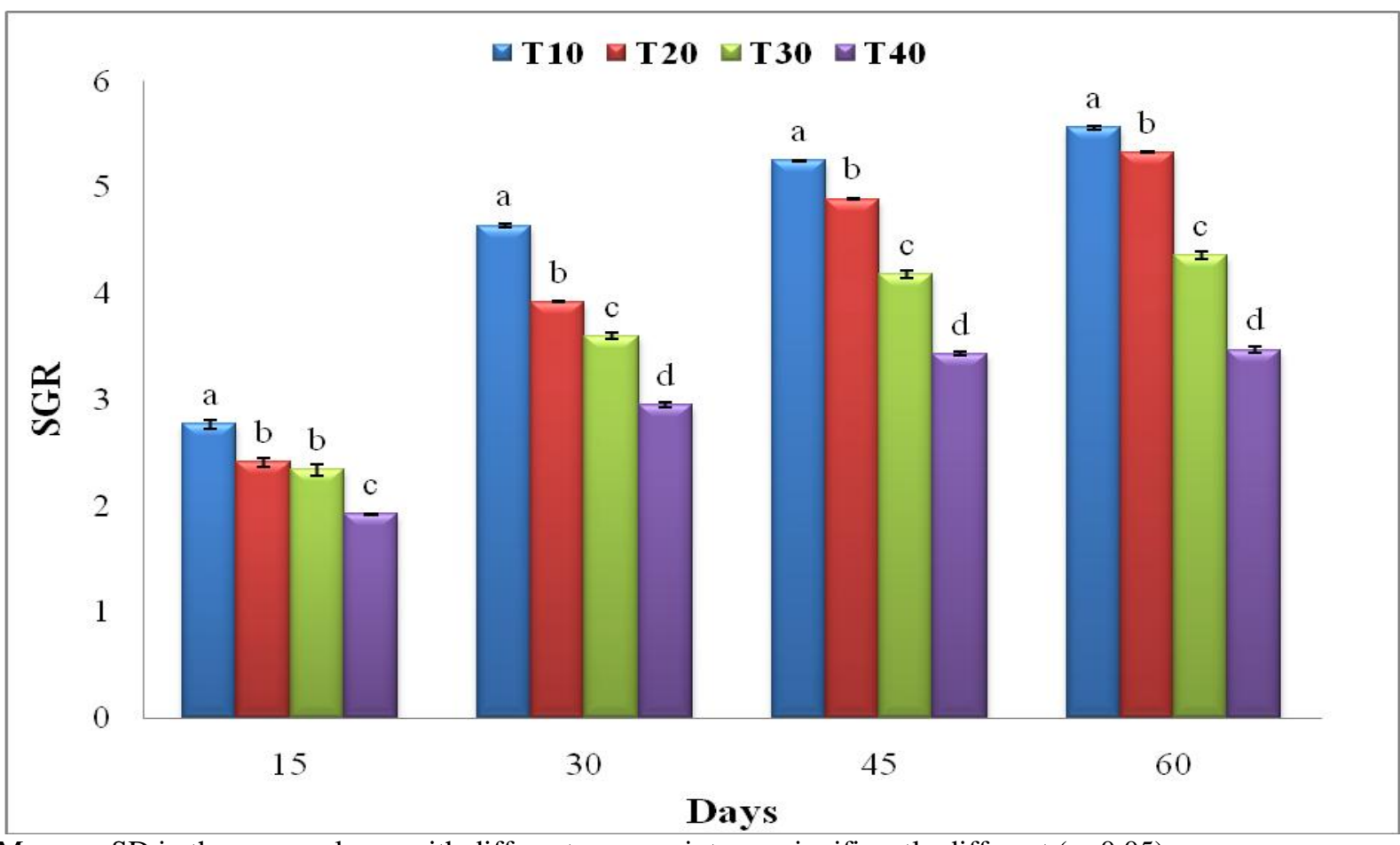

*Means \pm SD in the same column with different superscripts are significantly different $(p<0.05)$ 
Fig.3 FCR of PL of $F$. merguiensis reared for 60 days in FRP tanks at different stocking density

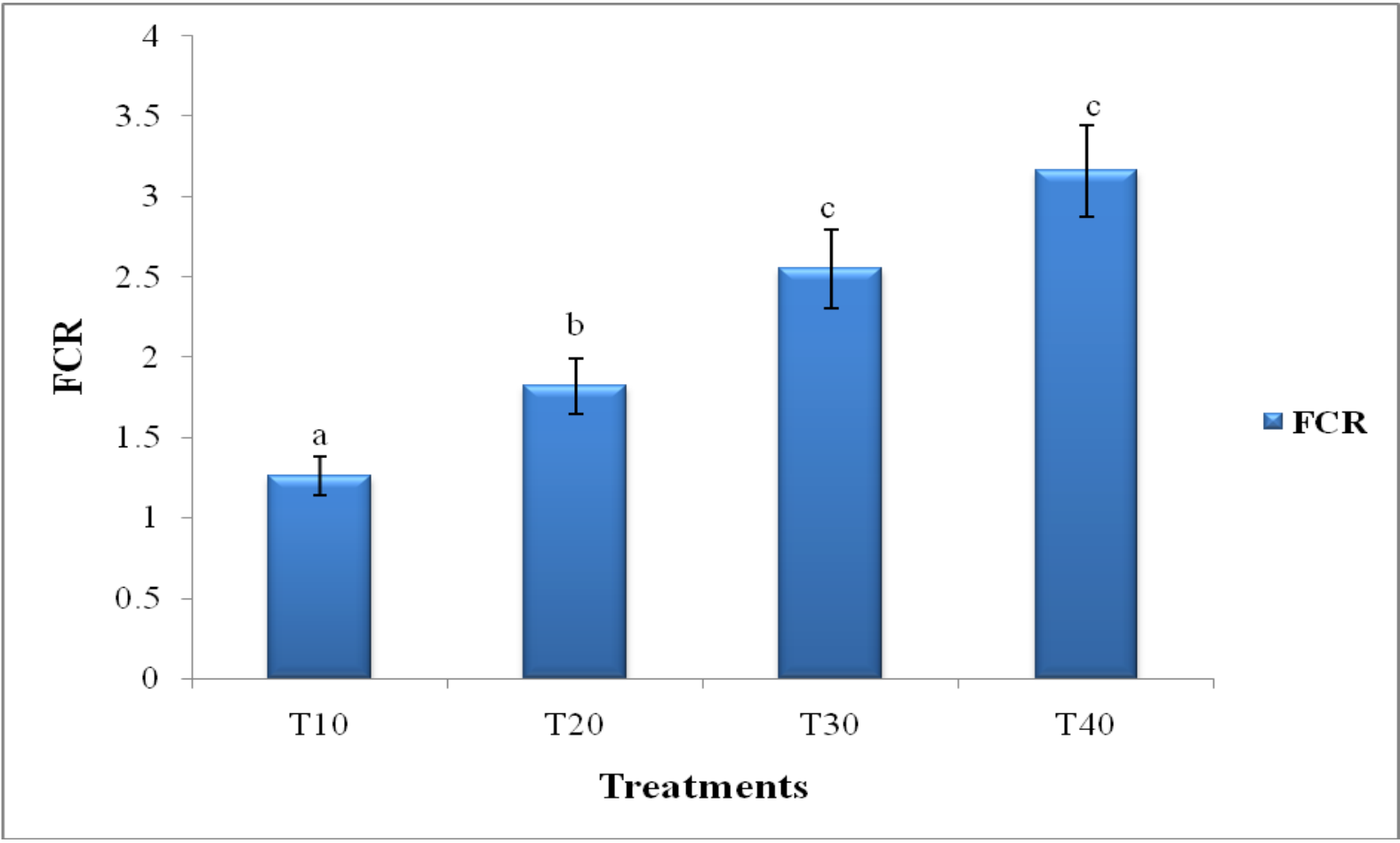

*Means \pm SD in the same column with different superscripts are significantly different $(\mathrm{p}<0.05)$

Fig.4 FCE and PER of PL of F. merguiensis reared for 60 days in FRP tanks at different stocking density

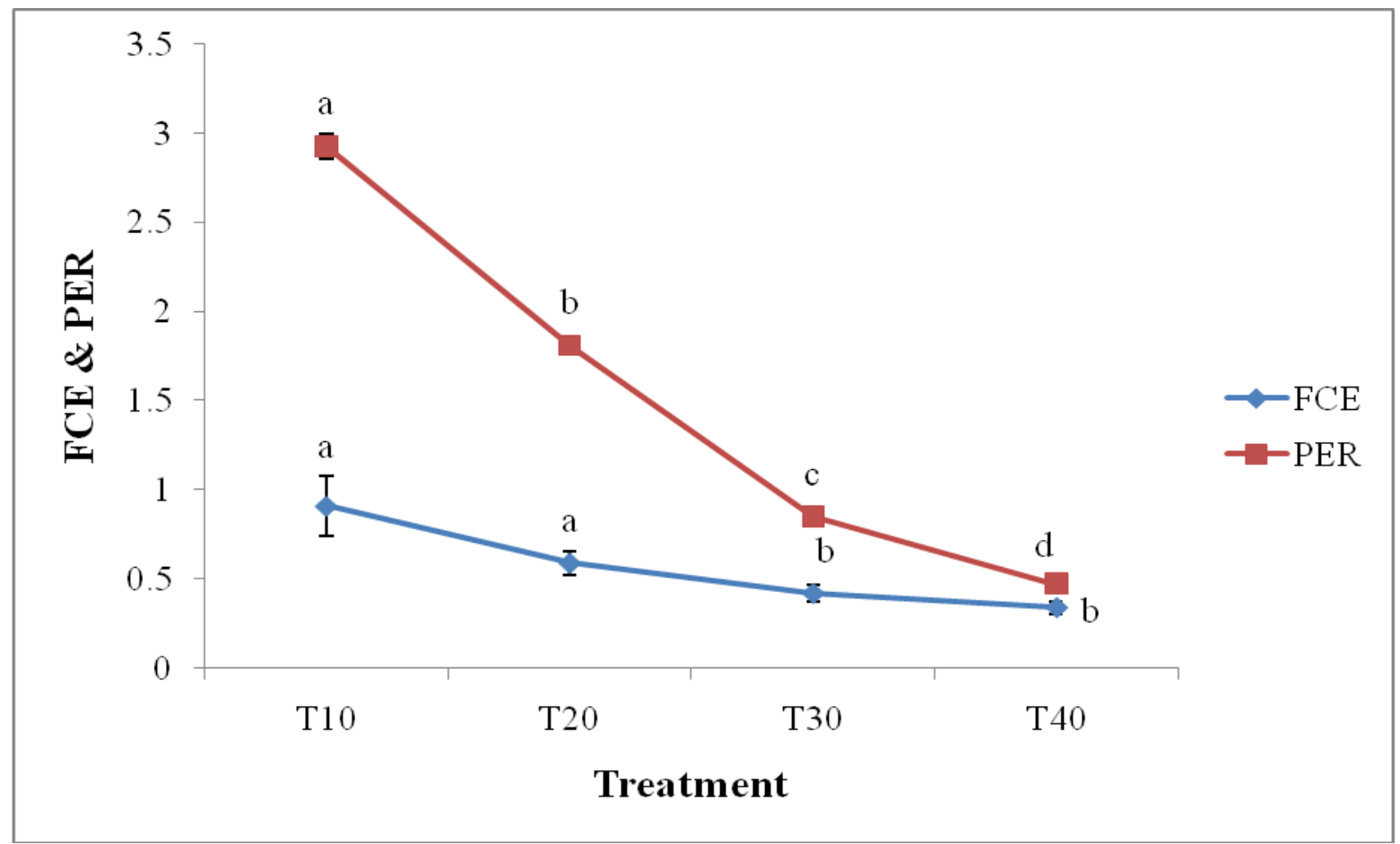

*Means \pm SD in the same column with different superscripts are significantly different $(\mathrm{p}<0.05)$ 
Fig.5 Survival (\%) of PL of F. merguiensis reared for 60 days in FRP tanks at different stocking density

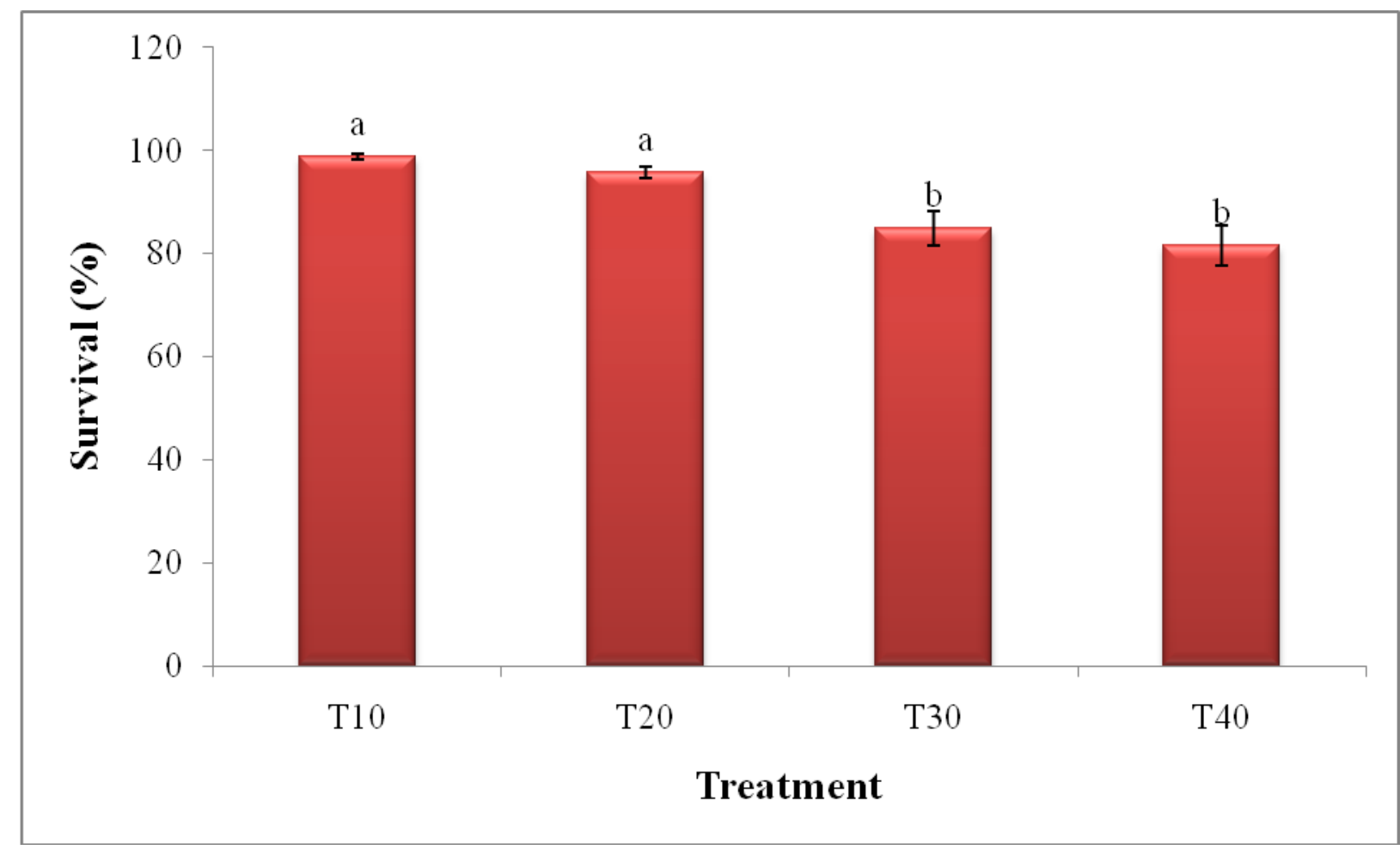

*Means \pm SD in the same column with different superscripts are significantly different $(p<0.05)$

Table.1 Temperature, salinity, $\mathrm{pH}$ and DO of water in the experimental tanks with Different stocking densities

\begin{tabular}{ccccc}
\hline Treatment & $\begin{array}{c}\text { DO } \\
(\mathbf{m g} / \mathbf{L})\end{array}$ & $\begin{array}{c}\text { Temperature } \\
\left({ }^{\mathbf{}} \mathbf{C}\right)\end{array}$ & $\begin{array}{c}\text { Salinity } \\
(\mathbf{m g} / \mathbf{L})\end{array}$ & $\mathbf{p H}$ \\
\hline T10 & $6.16 \pm 0.09^{\mathrm{a}}$ & $27.32 \pm 1.11^{\mathrm{a}}$ & $32.01 \pm 0.33^{\mathrm{a}}$ & $8.1 \pm 0.20^{\mathrm{a}}$ \\
T20 & $5.84 \pm 0.12^{\mathrm{b}}$ & $27.47 \pm 1.23^{\mathrm{a}}$ & $32.07 \pm 0.34^{\mathrm{a}}$ & $8.0 \pm 0.15^{\mathrm{a}}$ \\
T30 & $5.53 \pm 0.06^{\mathrm{c}}$ & $27.51 \pm 1.21^{\mathrm{a}}$ & $31.84 \pm 0.34^{\mathrm{a}}$ & $7.9 \pm 0.05^{\mathrm{a}}$ \\
T40 & $5.18 \pm 0.09^{\mathrm{d}}$ & $27.69 \pm 1.33^{\mathrm{a}}$ & $31.73 \pm 0.32^{\mathrm{a}}$ & $7.9 \pm 0.05^{\mathrm{a}}$ \\
\hline
\end{tabular}

* Mean \pm standard deviation in the same column with different superscripts are significantly different $(\mathrm{p}<0.05)$

Table.2 TAN, $\mathrm{NO}_{2}-\mathrm{N}, \mathrm{NO}_{3}-\mathrm{N}$ and $\mathrm{PO}_{4}-\mathrm{P}$ content of water in the experimental tanks with Different stocking densities

\begin{tabular}{ccccc}
\hline Treatment & $\begin{array}{c}\text { TAN } \\
(\mathbf{m g} / \mathbf{L})\end{array}$ & $\begin{array}{c}\mathbf{N O}_{2}-\mathbf{N} \\
(\mathbf{m g} / \mathbf{L})\end{array}$ & $\begin{array}{c}\mathbf{N O}_{\mathbf{3}}-\mathbf{N} \\
(\mathbf{m g} / \mathbf{L})\end{array}$ & $\begin{array}{c}\mathbf{P O}_{\mathbf{4}}-\mathbf{P} \\
(\mathbf{m g} / \mathbf{L})\end{array}$ \\
\hline T10 & $0.20 \pm 0.03^{\mathrm{a}}$ & $0.122 \pm 0.02^{\mathrm{a}}$ & $0.216 \pm 0.02^{\mathrm{a}}$ & $0.18 \pm 0.04^{\mathrm{a}}$ \\
$\mathrm{T} 20$ & $0.29 \pm 0.03^{\mathrm{a}}$ & $0.135 \pm 0.03^{\mathrm{a}}$ & $0.290 \pm 0.02^{\mathrm{ab}}$ & $0.33 \pm 0.03^{\mathrm{ab}}$ \\
T30 & $0.31 \pm 0.02^{\mathrm{b}}$ & $0.148 \pm 0.02^{\mathrm{a}}$ & $0.372 \pm 0.03^{\mathrm{bc}}$ & $0.55 \pm 0.09^{\mathrm{b}}$ \\
T40 & $0.34 \pm 0.01^{\mathrm{b}}$ & $0.171 \pm 0.03^{\mathrm{a}}$ & $0.405 \pm 0.04^{\mathrm{c}}$ & $0.92 \pm 0.19^{\mathrm{c}}$ \\
\hline
\end{tabular}

$*$ Mean \pm standard deviation in the same column with different superscripts are significantly different $(p<0.05)$ 
Lowest value of $\mathrm{NO}_{3}-\mathrm{N}$ was observed in $\mathrm{T} 10$ and highest value was noted for T40. The values of $\mathrm{NO}_{2}-\mathrm{N}$ and $\mathrm{NO}_{3}-\mathrm{N}$ were also well below safe levels. Similar result was obtained by Arnold et al., (2006) for tiger shrimp (Penaeus monodon) intensively grown from $\mathrm{PL}_{15}$ for $56 \mathrm{~d}$ in tank systems at different stocking densities, with and without the addition of artificial substrates. The detected phosphate level in the experimental tanks was from $0.18 \pm 0.04$ to $0.92 \pm 0.19 \mathrm{mg} / \mathrm{L}$. The level of $\mathrm{PO}_{4}-\mathrm{P}$ was found significantly different $(p<0.05)$ among the treatments. Water quality declined at high stocking densities (T30 and T40) and nitrogenous compounds and phosphate were higher. But, it was observed that in general, mean water quality parameters in all the treatments were within the level recommended for culturing penaeids.

\section{Growth performance parameters of PL of} F. merguiensis

It is well known that stocking density influences growth and survival of shrimp and an inverse relationship between these factors are generally reported (Wasielesky et al., 2013). In the present experiment, the average final individual weight of PL of $F$. merguiensis decreased significantly $(\mathrm{p}<0.05)$ with increasing stocking density. At the end of the experiment, the final biomass found significantly $(\mathrm{p}<0.05)$ higher in T10 and T20 compared to T30 and T40. The mean final weights found in T10, T20, T30 and T40 were $5.95,4.83,3.83$ and $3.27 \mathrm{~g}$ respectively, at the end of 60 days of the experiment. Similar result was declared by Sookying et al., (2011) for pacific white shrimp. They revealed a significantly higher mean final weight in the low density groups compared with higher densities. Body weight gain (\%), among the treatments, for PL of $F$. merguiensis ranged from $216.19 \pm 7.45$ to $426.67 \pm 12.95$ as shown in figure 1. Increase in stocking density led to significant reduction $(\mathrm{p}<0.05)$ in BWG and SGR of PL. Similar observation was found by Balakrishnan et al., (2011). They revealed average body weight increased when stocking density was low. BWG (\%) on $15^{\text {th }}$ day of current experiment showed significant difference $(p<0.05)$ among the treatments. The highest BWG observed in T10 having stocking density of 10 shrimp $\mathrm{PL} /$ tank and the lowest BWG was seen in treatment T40 with stocking density of 40 shrimp PL/tank. On $30^{\text {th }}$ day, BWG was in the range of $86.14 \pm 2.36 \%$ to $207.23 \pm 5.5 \%$ and it varied from $32.74 \pm 2.39 \%$ to $78.8 \pm$ $0.99 \%$ on $45^{\text {th }}$ day. At the end of the experiment, BWG was highest in T10 (29.95 $\pm 1.85 \%)$ and lowest in T40 (2.79 $\pm 0.62 \%)$. The negative relationship between stocking density and average body weight was also reported by Krishna et al., (2015). Values of SGR obtained for PL of $F$. merguiensis reared under captive condition at different stocking density is shown in figure 2. Significant $(\mathrm{p}<0.05)$ differences in SGR of $F$. merguiensis were found between the tanks with different stocking density. Highest SGR were observed in the T10 and lowest in T40. Similar observation was done by Araneda et al., (2008), Williams et al., (1996) and Sookying et al., (2011), who reported that that increasing density and shrimp biomass had negative effect on growth.

FCR is always a prime concern for shrimp farmers. At the end of the study, the FCR was found in the range of $1.25 \pm 0.12$ to $3.16 \pm 0.28$, as depicted in figure 3. FCR increased with increased shrimp density and significant $(p<0.05)$ differences in FCR were found among the treatments. Highest value of FCR was obtained for T40, whereas lowest one was recorded in T10. Similar result was obtained by Shakir et al., (2014) for Penaeus monodon. FCR in T40 and T30 was significantly higher than T10. The values of FCE obtained for banana shrimp PL in the 
experiment is shown in figure 4. The FCE ranged from $0.34 \pm 0.03$ to $0.91 \pm 1.71$. Highest FCE were recorded in T10 and the lowest in T40. Significant differences $(p<0.05)$ were observed for FCE of T10 and T40. T10 showed no significant $(\mathrm{p}<0.05)$ difference in FCE value from T20. Protein efficiency ratio (PER) indicates the better utilization of dietary protein. In the present study, values of PER varied from 2.90 \pm 0.07 to $0.47 \pm 0.01$ for PL of $F$. merguiensis reared for 60 days. Highest PER value was recorded in T10 and lowest in T40 as depicted in figure 4. It may be due to overcrowding and competition for food and space, which ultimately leads to stressful conditions for the cultured shrimps. Observed results match with the findings of Chakraborty et al., (1997) for tiger shrimp (Penaeus monodon fab.) fed on commercial formulated diets. Survival percentage of PL of $F$. merguiensis ranged from $98.81 \pm 0.61$ to $81.46 \pm 3.85$ (Figure 5). Significant differences $(\mathrm{p}<0.05)$ were found in survival percentage among the treatments. Survival rate was significantly $(\mathrm{p}<0.05)$ lower in the treatments with higher stocking density (T30 and T40) and highest rate of survival was observed in T10. Similar result was reported by Apud (1981) for P. monodon, where high stocking density resulted significant $(\mathrm{p}<0.05)$ reductions in survival. $\mathrm{Li}$ et al., (2006) also observed that high stocking density negatively influenced the growth and survival rate of Chinese shrimp, Fenneropenaeus chinensis. Survival percentage observed in the present study suggested that stocking density $\geq 30 / \mathrm{m}^{2}$ had affected shrimp survival.

Stocking density is a very important factor in shrimp culture. It significantly affects the growth, survival and yield of shrimp growth. Many of the previous researchers have also reported that growth of shrimp generally decreased, when stocking density increased. The reduced water quality, along with the physical stress caused by crowding at higher stocking densities, could be the reasons for lower growth performance. Similarly, results of the present study revealed that high stocking density $\left(\geq 30 / \mathrm{m}^{2}\right)$ can seriously impair the growth of $F$. merguiensis PL.

\section{Acknowledgements}

The authors would like to thank the Director, Indian Council of Agricultural ResearchCIFE, Mumbai, for the financial assistance and Director, ICAR-CMFRI, Cochin, for providing facilities to carry out this work. The first author is also thankful to SIC, ICARCMFRI, Veraval RC, SIC, ICAR-CIFT, Veraval RC and the Head, Aquaculture division, ICAR-CIFE for their help and encouragement. The authors also declare that there is no conflict of interest.

\section{References}

Aguilar, V., Racotta, I. S., Goytortúa, E., Wille, M., Sorgeloos, P., Civera, R., Palacios, E. 2012. The influence of dietary arachidonic acid on the immune response and performance of Pacific whiteleg shrimp, Litopenaeus vannamei, at high stocking density. Aquac. Nutr. 18: 258-271

APHA, 1995. Standard Methods for the Examination of Water and Waste Water, 20 ${ }^{\text {th }}$ Edition. American Public Health Association, Washington DC

APHA, 1998. Standard Methods for the Examination of Water and Waste Water, 20 ${ }^{\text {th }}$ Edition. American Public Health Association, Washington DC

Apud, F. D., 1985. Extensive and semiintensive culture of prawn and shrimp in the Philippines, 105-113 p, SAFDC Aquaculture Department, Iliola, The Philippines

Araneda, M., Pérez, E. P., Gasca-Leyva, E. 2008. White shrimp Penaeus vannamei 
culture in freshwater at three densities: condition state based on length and weight. Aquaculture. 283: 13-18

Arnold, S. J., Sellars, M. J., Crocos, P. J., Coman, G. J. 2006. Intensive production of juvenile tiger shrimp Penaeus monodon: An evaluation of stocking density and artificial substrates. Aquaculture. 261: 890-896

Balakrishnan, G., Peyail, S., Ramachandran, K., Theivasigamani, A., Savji, K. A., Chokkaiah, M., Nataraj, P. 2011. Growth of cultured whiteleg Shrimp Litopenaeus vannamei (Boone 1931) in different stocking density. Adv in Appl Sci Res. 2 (3): 107-113

Bray, W. A., Lawrence, A. L. 1992. Reproduction of peaneus species in captivity. In: Marine shrimp culture: Principle and practices (Fast, A. W. And Lester, J. L., Eds.), pp 93-170, Elsevier, Netherlands

Chakraborty, S. C., Paul, A. K., Hossain, M. A. 1997. Effect of stocking density on growth of tiger shrimp (Penaeus monodon fab.) fed oncommercial formulated diets Bangladesh. Fish. Res. 1(1): 53-63

Christina, M. S., Achuthankutty, C. T. 2000. Growth of hatchery raised banana shrimp Penaeus merguiensis (de Man) (Crustacea: Decapoda) juveniles under different salinity. Indian J Mar Sci. 29: $179-18$

Cook, H. L., Murphy, M. A. 1969. The culture of larval penaeid shrimp. Trans. Am. Fish. Soc. 98 (4): 751-754

Correia, E.S., Wilkenfeld, J.S., Morris, T.C., Wei, L.W., Prangnell, D.I., Samocha, T.M. 2014. Intensive nursery production of the Pacific white shrimp Litopenaeus vannamei using two commercial feeds with high and low protein content in a biofloc-dominated system. Aquac. Eng. 59, 48-54

Hoanga, T., Leea, S. Y., Keenan, C. P.,
Marsden, G. E. 2002. Effect of temperature on spawning of Penaeus merguiensis. J Therm Biol. 27: 433437.

Hudinaga, M., 1942. Reproduction, development and rearing of Penaeus japonicas Bate. Jap. J. Zoo. 10 (2): 305393

Krishna, P. V., Bhanu Prakash, K., Hemanth Kumar, V., Prabhavathi, K. 2015. Growth, survival and production of Pacific White Shrimp Litopenaeus vannamei at different stocking densities under semi intensive culture systems in Andhra Pradesh. Inter J of Adv Res. 3 (9): 446 - 452

Li, Y., Li, J., Wang, Q. 2006. The effects of dissolved oxygen concentration and stocking density on growth and nonspecific immunity factors in Chinese shrimp, Fenneropenaeus chinensis. Aquaculture. 256: 608-616

Liu, G., Zhu, S., Liu, D., Guo, X., Ye, Z. 2017. Effects of stocking density of the white shrimp Litopenaeus vannamei (Boone) on immunities, antioxidant status, and resistance against Vibrio harveyi in a biofloc system. Fish. Shellfish Immunol. 67: 19-26

Rahman, M. R., Rahman, M. A. 2003. Studies on the growth, survival and production of calbasu (Labeo calbaus Ham.) fry at different stocking densities in primary nursing. Bull. Fac. Sci., Univ. Ryuyus, Jpn. 76: 245-255

Shakir. C., Lipton, A. P., Manilal, A., Sugathanand, S., Selvin, J. 2014. Effect of stocking density on the survival rate and growth performance in Penaeus monodon. J of Bas and Appl Sci. 10: 231-238

Shyne Anand, P. S., Pillai, S. M., Sujeet Kumar, Panigrahi, A., Ravichandran, P., Ponniah, A. G., Ghoshal, T. K. 2014. Growth, survival and length weight relationship of Fenneropenaeus 
merguiensis at two different stocking densities in low saline zero water exchange brackishwater ponds. Indian J Geo-Mar Sci. 43: 1955-1966

Sookying, D., D’Silva, F. S., Allen Davis D., Hanson, T. R. 2011. Effects of stocking density on the performance of Pacific white shrimp Litopenaeus vannamei cultured under pond and outdoor tank conditions using a high soybean meal diet. Aquaculture. 319: 232-239

Wang. X., Ma, M., Dong, S., Cao, M. 2004. Effects of salinity and dietary carbohydrate levels on growth and energy budget of juvenile L.vannamei. $\mathrm{J}$ Shell fish Research. 23: 231 - 236
Krummenauer, D., Lara, G., Poersch, L. 2013. Nursery of Litopenaeus vannamei reared in a biofloc system: the effect of stocking densities and compensatory growth. J. Shellfish Res. 32: 799-806

Williams, A. S., Davis, D. A., Arnold, C. R. 1996. Density-dependent growth and survival of Penaeus setiferus and Penaeus vannamei in a semi-closed recirculating system. J World Aqua Soc. 27: $107-112$

Zacharia, S., Kakatiz, V.S. 2002. Growth and survival of Peneaus mergunsis post larvae at different salinities. The Israeli Journal of Aquaculture-Bamidgeh. 54(4): $157-162$

\section{How to cite this article:}

Vivek Shrivastava, N.K. Chadha, Md. Koya, W.S. Lakra, Paramita Banerjee Sawant and Remya, S. 2017. Effect of Stocking Density on Growth and Survival of Fenneropenaeus merguiensis (de Man, 1888) Post Larvae. Int.J.Curr.Microbiol.App.Sci. 6(9): 1779-1789. doi: https://doi.org/10.20546/ijcmas.2017.609.220 